\title{
41. PETROGRAPHIC AND CHEMICAL CHARACTERISTICS OF PYRITE-MARCASITE MINERALIZATION IN HOLE 465A, SOUTHERN HESS RISE ${ }^{1}$
}

\author{
Randolph A. Koski and James R. Hein, U.S. Geological Survey, Menlo Park, California
}

\begin{abstract}
Core recovered from Hess Rise contains concentrations of pyrite, marcasite, and barite in the lowermost meter of limestone (Unit II) and in the brecciated upper part of the underlying volcanic basement (Unit III). Petrographic and chemical data indicate that the sulfide-barite assemblage in the limestone is mainly a product of low-temperature diagenetic processes. The iron-sulfide phases are biogenic and their concentrations mark the diffusion of sea water sulfate through sedimentary horizons containing abundant organic matter and mafic, glassy volcanogenic detritus. There is some evidence, however, that elevated temperatures augmented or intensified the synsedimentary diagenetic process.
\end{abstract}

\section{INTRODUCTION}

Iron sulfide minerals are common constituents of ancient marine sedimentary rocks (Edwards and Baker, 1951; Curtis, 1967; Love and Amstutz, 1966) as well as modern marine sediments (Love, 1967; Berner, 1970; Hein and Griggs, 1972; Sweeney and Kaplan, 1973). Sediments cored by DSDP generally contain small amounts of disseminated pyrite and marcasite, but only a few examples of concentrated occurrences of these minerals have been described (Kelts, 1976; Siesser, 1978).

The lowermost meter of limestone (Unit II) from Hole 465A on Hess Rise contains layered concentrations of pyrite, marcasite, and barite (Fig. 1). The sulfide mineralization extends downward into the brecciated upper part of the underlying volcanic basement (Unit III). On the basis of petrographic, X-ray-diffraction, and chemical data for whole rocks and iron sulfide separates from stratigraphic intervals where the iron sulfide occurs, we propose that the sulfides and associated barite are mainly products of low-temperature diagenetic processes in the limestone.

\section{METHODS}

Samples from four zones of iron sulfide mineralization in limestone and a single sample of iron sulfide crust from brecciated trachyte were studied. Textures and mineralogy were determined from examination of polished thin sections, using both transmitted and reflected light. Mineral compositions also were determined by X-ray diffraction of several powdered sub-samples from each interval. Major- and trace-element compositions for three bulk samples were obtained by quantitative emission spectroscopy at the Branch of Analytical Laboratories, U.S. Geological Survey.

Surface morphologies and chemical compositions of sulfidebearing samples were examined with a Cambridge Stereoscan 180 scanning electron microscope (SEM) coupled with an energy-dispersive X-ray analyzer (EDAX). Sample chips were mounted on aluminum plugs and carbon coated in a vacuum evaporator prior to analysis. Individual iron sulfide grains were analyzed for $\mathrm{Fe}, \mathrm{S}, \mathrm{Cu}$, $\mathrm{Co}, \mathrm{Ni}$, and As with an ARL-EMX electron microprobe, operating with an accelerating voltage of $15 \mathrm{kv}$ and a specimen current of 1.5 microamps. Synthetic sulfide phases were used for standards. Micro-

\footnotetext{
1 Initial Reports of the Deep Sea Drilling Project, Volume 62.
}

probe data were corrected and compositions were calculated on-line using the FRAME program of Yakowitz and others (1973).

\section{LITHOLOGY}

Unit II has a thickness of 136 meters and consists of upper Albian to lower Cenomanian laminated, olivegray limestone, with subordinate amounts of gray limestone and black chert (Fig. 1). Immediately above the volcanic basement, the limestone is massive to laminated, with considerable color variation. Thin laminations result from numerous partings of organic-matterrich material. Thicker beds contain volcanogenic components, clastic dolomite, barite, iron sulfide, and organic matter. In the basal meter of limestone, four separate layers of massive and disseminated iron sulfide are present (Fig. 1). Above this section, pyrite is disseminated in minor amounts regardless of lithology.

About 24 meters of altered trachyte was recovered beneath the limestone (Vallier and others, 1980). Coarse volcanic breccia in the upper part of the volcanic basement is underlain by fine-grained, vesicular trachytic lava. Iron sulfide, barite, and carbonate form veinlets and disseminations within the volcanic breccia fragments, as well as thin coatings on fragments.

\section{PETROGRAPHY}

Within the lower meter of limestone (Unit II), ironsulfide-rich zones are separated by carbonate intervals containing lesser amounts of disseminated sulfide. The concentrations of sulfide consist of loosely packed to massive polycrystalline layers of iron sulfide averaging 0.5 to $1 \mathrm{~cm}$ in thickness. Isolated sulfide grains or small aggregates are abundant above and below the sulfiderich layers. The layered aggregates have undulating tops and bottoms that locally protrude as lobes upward and downward into enclosing sediment (Fig. 2).

Close-packed sulfide aggregates commonly contain dispersed clasts of mafic volcanic rock and altered volcanic glass, and interstitial carbonate, barite, and organic(?) matter. In Sample 40-2, 18-20 cm, iron sulfide constitutes the matrix enclosing detrital volcanogenic material. 


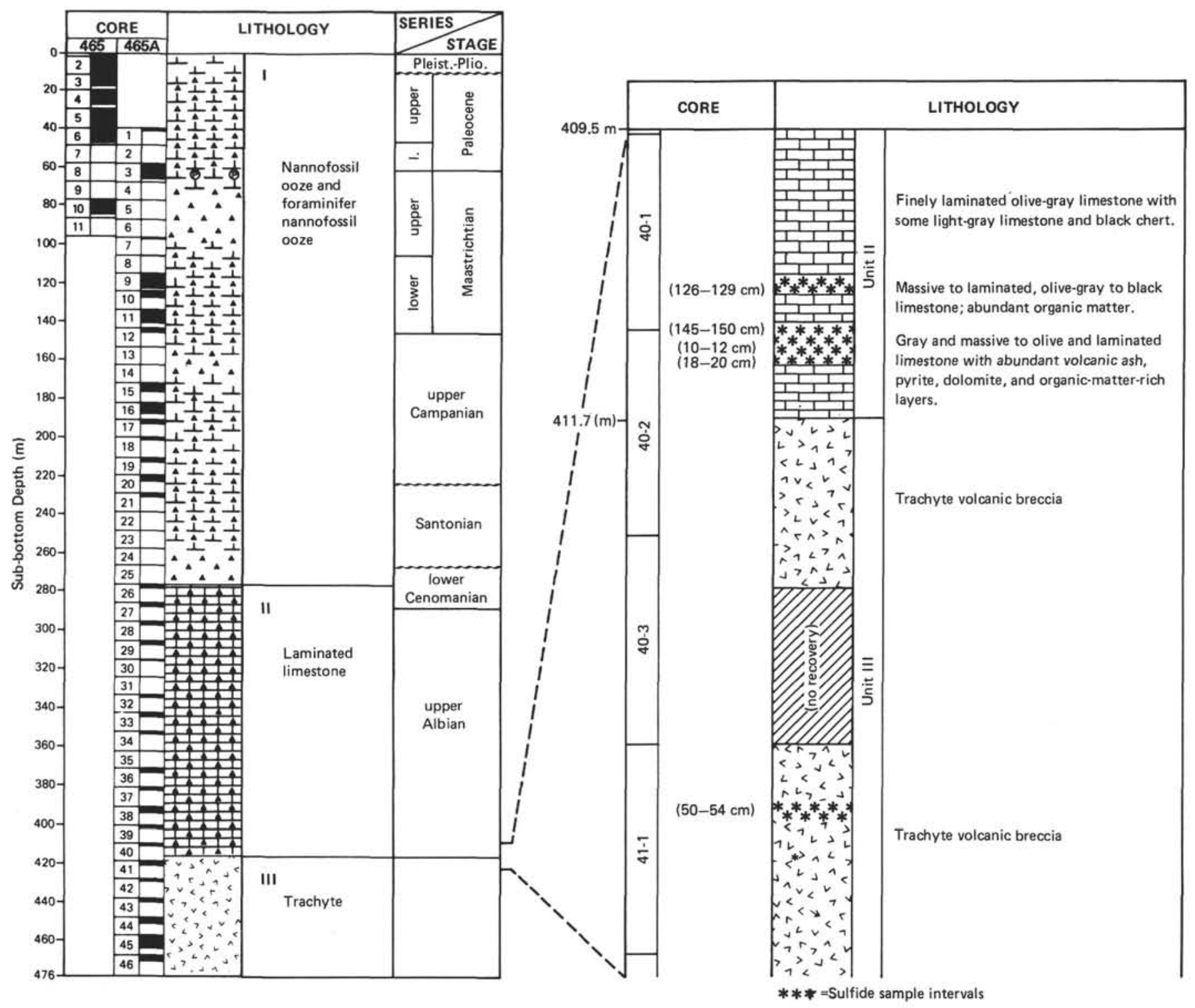

Figure 1. Lithology of Hole 465A and location of iron sulfide samples in Units II and III.

The mineral composition of sulfide-rich layers and adjacent wall rock is presented in Table 1 . Two sulfide phases were identified: the cubic and orthorhombic polymorphs of $\mathrm{FeS}_{2}$, pyrite and marcasite. Pyrite occurs alone at $40-1,145-150 \mathrm{~cm}$ and $40-2,10-12 \mathrm{~cm}$, whereas pyrite and marcasite are both abundant at 40-1, 126-129 $\mathrm{cm}$; marcasite occurs in the other samples, but is subordinate to pyrite. Marcasite was not detected megascopically in any of the samples.

Isolated pyrite grains and pyrite grains in layered aggregates occur as well-formed cubes, octahedrons and pyritohedrons, or combinations of these forms (Fig. $3 \mathrm{~A})$. Grain size is highly variable within any single layer, commonly ranging from 0.5 to $2 \mathrm{~mm}$. In massive polycrystalline aggregates, anhedral to euhedral pyrite forms an interlocking mosaic; triple points are common. Pyrite/pyrite grain boundaries are generally smooth and straight to slightly curvilinear, but some contacts are rough and mutually interfering. Coarse striations occur on many crystal faces (Fig. 3B). Fine-grained spherical sulfide aggregates or framboidal textures were not observed in any of the rocks.

Marcasite occurs as small rectangular, triangular, and subhedral blebs within pyrite grains, but the reverse is also true, with coarser-grained marcasite hosting small anhedral pyrite blebs. In places, larger marcasite grains exhibit a few coarse twin lamellae. Marcasite is not randomly distributed within sulfide aggregates, but is concentrated in clusters, particularly near the margins of massive pyrite zones (Fig. 4).

In addition to iron sulfide, secondary minerals include barite, gypsum, jarosite, calcite, dolomite, and zeolite. Coarse (to $3 \mathrm{~mm}$ in length), tabular barite is most abundant along the margins of iron sulfide layers, where it constitutes the matrix enclosing volcanic detritus (Fig. 5). Where barite is in contact with or interstitial to pyrite, the edges of barite grains are etched and eroded. SEM examination of massive pyrite from $40-1$, $126-129 \mathrm{~cm}$ showed slender prismatic crystals as much as $50 \mu \mathrm{m}$ in length forming radiating clusters along 


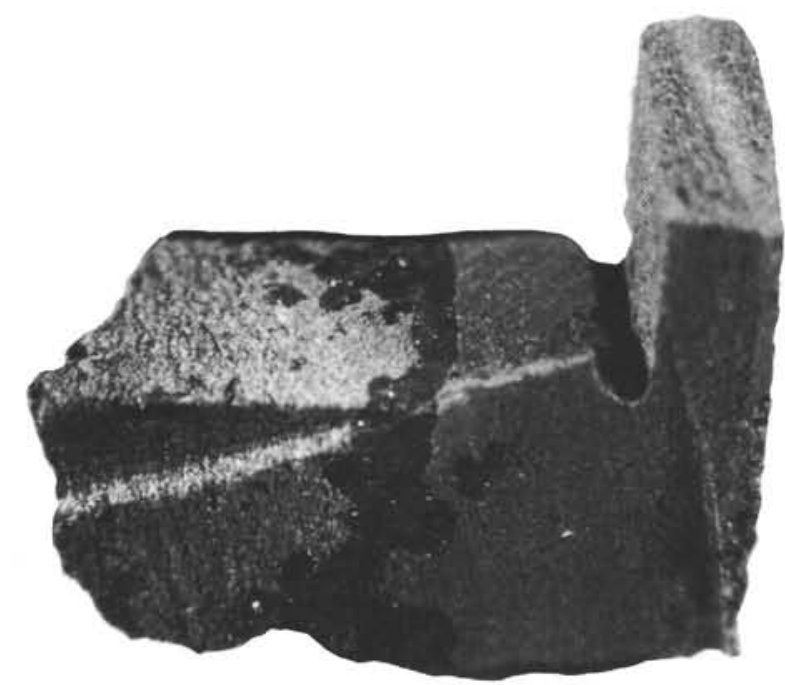

Figure 2. Core chip from $465 \mathrm{~A}-40-1,126-129 \mathrm{~cm}$, with 1-cm thick layer of iron sulfide interbedded with carbonate. Note lobate projections of iron sulfide protruding into wall rock and isolated sulfide aggregates in wall rock.

pyrite surfaces and grain boundaries (Fig. 6). The presence of $\mathrm{Ca}$ and $\mathrm{S}$, determined by EDAX, and of swallowtail twinning, identifies the radiating clusters as gypsum. Gypsum crystals with a similar morphology are associated with authigenic pyrite in sediments recovered from the coast of Southwest Africa (Siesser and Rogers, 1976). A third sulfate phase, jarosite, is a component of the very fine-grained matrix in Sample 40-2, 18-20 cm.

Calcite and dolomite occur in pure polycrystalline aggregates adjacent to sulfide layers. Dolomite rhombs are present within the margins of sulfide masses. Carbonate also occurs in interlocking aggregates with barite, filling the interstices between large barite blades, and as small replacement aggregates in barite crystals.

In Samples 40-1, 145-150 cm and 40-2, 18-20 cm, small, colorless, low-birefringent crystals of clinoptilolite are intergrown with barite and carbonate.

Several sulfide-rich layers in the limestone contain abundant sand-sized detritus composed of altered holocrystalline or hypocrystalline volcanic rock, plagioclase, quartz, and rare biotite. Volcanic-rock textures are trachytic or intersertal, in which tightly packed plagioclase laths are enclosed in a matrix of dark-gray, recrystallized glass. The textures are similar to those in the trachyte underlying the limestone of Unit II. Mafic minerals in the lithic fragments appear to be largely altered, but X-ray-diffraction studies show some relict pyroxene. Volcanic lithic clasts are subrounded to rounded and occur in well-sorted, loosely packed aggregates in matrix consisting of pyrite, barite, carbonate, or combinations of these minerals. Grain boundaries between lithic grains and barite and lithic grains and carbonate tend to be sharp and smooth, whereas contacts between lithic grains and pyrite are sutured and ragged.

Within the sulfide layers, volcanic lithic grains display slight to nearly complete replacement by pyrite. This type of replacement begins with encroachment along the grain edges and with formation of disseminated pyrite clots in the grain interior. In advanced stages, pyrite replaces the entire groundmass of the lithic grain, leaving plagioclase laths floating in massive sulfide (Fig. 7). Lithic volcanic grains with a very finegrained or glassy groundmass appear to be more susceptible to replacement than those in which the groundmass is felty and feldspathic.

The shipboard lithologic summary for Hole $465 \mathrm{~A}$ notes that volcanic ash was first observed at 40-1, 143$148 \mathrm{~cm}$, where it is interlayered with olive-gray limestone, dolomite, organic matter, and pyrite. According to Hein and Vanek (this volume), the mineralogy and chemistry of volcanic ash in the lowermost meter of limestone at Hole 465A are similar to that of the underlying trachyte. Petrographically, the tuffaceous zones consist of pale-brown, recrystallized glass admixed with variable amounts of carbonate, barite, zeolite, pyrite, and iron oxide. Smectite, occurring in some samples, probably represents an alteration product of volcanic ash (Hein and Vanek, this volume).

Organic matter occurs in sedimentary wall rock adjacent to the iron-sulfide-rich zones in the form of wispy, undulatory microlaminations and discontinuous strands that define a crude bedding. Some interstices between tightly packed pyrite grains are also filled with dark-

Table 1. Mineralogy of sulfide-rich zones and adjacent wall rock.

\begin{tabular}{|c|c|c|c|c|}
\hline $\begin{array}{l}\text { Sample } \\
\text { (interval in } \mathrm{cm} \text { ) }\end{array}$ & Material & Major & Moderate & Minor/Trace \\
\hline \multicolumn{5}{|l|}{ Unit II } \\
\hline \multirow[t]{2}{*}{$465 \mathrm{~A}-40-1,126-129$} & Sulfide layer & Marcasite, pyrite & & Gypsum \\
\hline & Gray limestone & Calcite & & Plagioclase, K-feldspar \\
\hline \multirow[t]{2}{*}{$465 \mathrm{~A}-40-1,145-150$} & Sulfide layer & Pyrite & $\begin{array}{l}\text { Dolomite, } \\
\text { clinoptilolite }\end{array}$ & $\begin{array}{l}\text { Barite, zeolite(?), } \\
\text { magnetite(?) }\end{array}$ \\
\hline & Gray ashy matrix & Dolomite & Plagioclase & $\begin{array}{l}\text { High-Mg calcite, pyrite, } \\
\text { barite, smectite, quartz. } \\
\text { biotite, natrolite(?) }\end{array}$ \\
\hline \multirow[t]{2}{*}{$465 \mathrm{~A}-40-2,10-12$} & Sulfide layer & Pyrite & Quartz, plagioclase & Dolomite, calcite, barite \\
\hline & Dolomitic limestone & Plagioclase & $\begin{array}{l}\text { Calcite, pyroxene, } \\
\text { quartz, dolomite }\end{array}$ & $\begin{array}{l}\text { Pyrite, smectite, } \\
\text { natrolite(?), apatite(?) }\end{array}$ \\
\hline \multirow[t]{2}{*}{$465 \mathrm{~A}-40-2,18-20$} & Sulfide- and barite-rich zone & Pyrite & Jarosite & $\begin{array}{l}\text { Barite, dolomite, calcite } \\
\text { clinoptilolite, marcasite }\end{array}$ \\
\hline & Pyritic carbonate & Dolomite, barite & & Pyrite, plagioclase, quart? \\
\hline \multicolumn{5}{|l|}{ Unit III } \\
\hline \multirow[t]{2}{*}{$465 \mathrm{~A}-41-1,50-54$} & Sulfide rim & Pyrite & & Marcasite \\
\hline & Trachyte & Plagioclase & Pyroxene & $\begin{array}{c}\text { Smectite, pyrite, quartz, } \\
\text { magnetite, apatite(?) }\end{array}$ \\
\hline
\end{tabular}



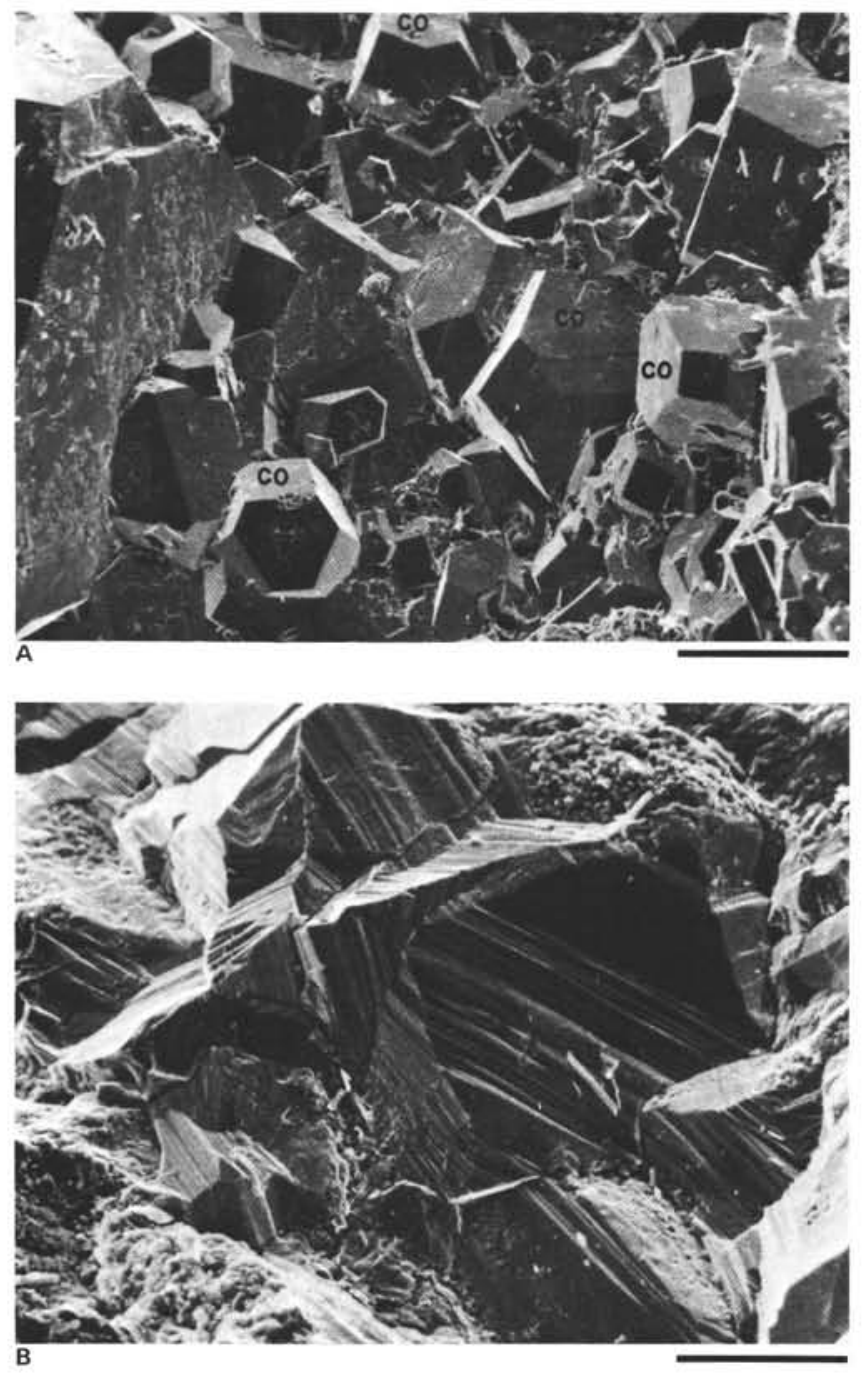

Figure 3. A. SEM photomicrograph of massive pyrite layer (40-1, $126-129 \mathrm{~cm}$ ), showing numerous cube-octahedron combinations (co); bar represents $0.3 \mathrm{~mm}$. B. Coarse striations on octahedral pyrite faces $(40-1,126-129 \mathrm{~cm})$; bar represents $0.1 \mathrm{~mm}$.

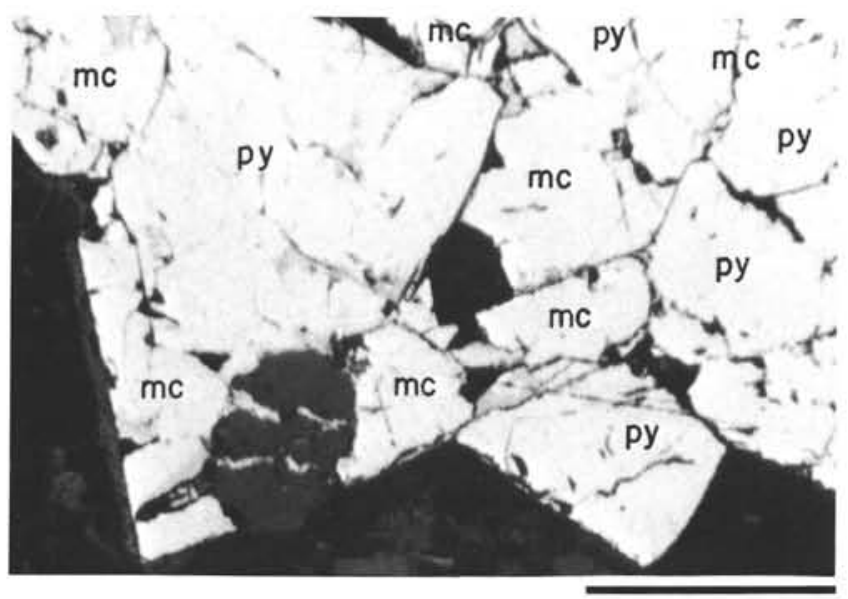

Figure 4. Photomicrograph showing subhedral marcasite grains clustered with coarser-grained pyrite $(40-2,18-20 \mathrm{~cm}) ; \mathrm{mc}=$ marcasite, $\mathrm{py}=$ pyrite; bar represents $0.1 \mathrm{~mm}$.

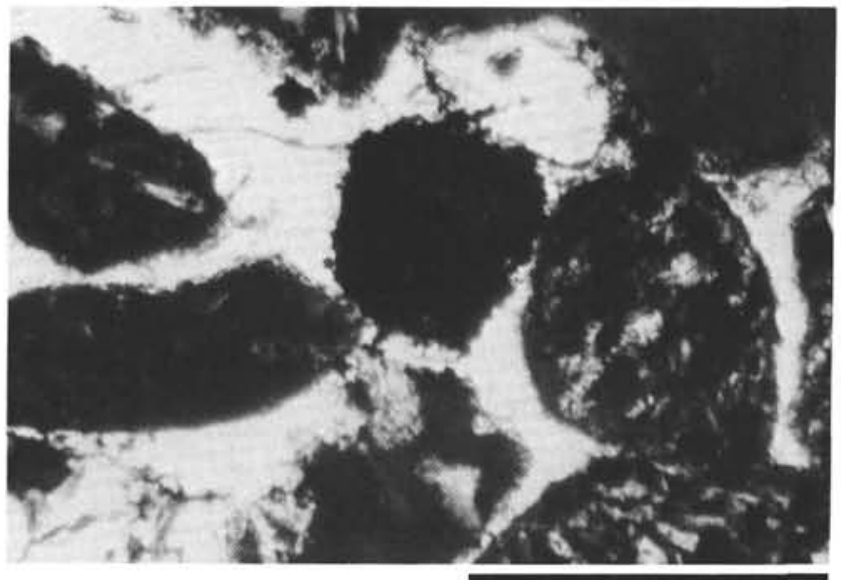

Figure 5. Photomicrograph showing coarse-grained barite matrix supporting subrounded volcanic lithic grains $(40-1,145-150 \mathrm{~cm})$; bar represents $0.25 \mathrm{~mm}$.

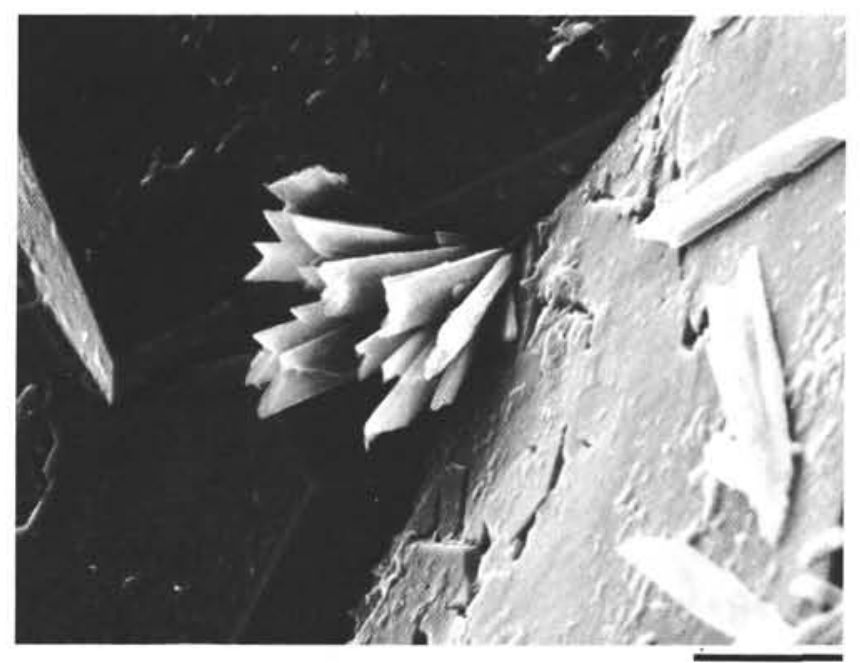

Figure 6. SEM photomicrograph of prismatic gypsum crystals exhibiting "swallowtail" twinning radiating from contact between pyrite grains (40-1, 126-129 cm); bar represents $0.01 \mathrm{~mm}$.

gray or black, amorphous material that may represent an organic residue. Organic-carbon content of Unit II limestone at Hole $465 \mathrm{~A}$ ranges from 0.1 to $8.6 \mathrm{wt} . \%$ (Dean, this volume). Petrographic studies by Timofeev and Bogolyubova (this volume) indicate that organic deposits in the lower section of Hole $465 \mathrm{~A}$ consist of a mixture of syngenic sapropelic and allothogenic (terrigenous) humic microcomponents, suggesting deposition in a near-shore, shallow-water environment.

Thin iron sulfide rims coating trachyte fragments in Unit III consist of pyrite containing small dispersed blebs of marcasite. The width of the rims varies from 0.2 to $0.5 \mathrm{~mm}$, a thickness encompassing one to five pyrite grains. Individual grains of pyrite are subhedral, with long dimensions perpendicular to the sulfide/ trachyte contact. The sawtooth texture appears to represent unimpeded open-space crystallization outward from the trachyte surface into a cavity or fracture in the breccia (Fig. 8). 


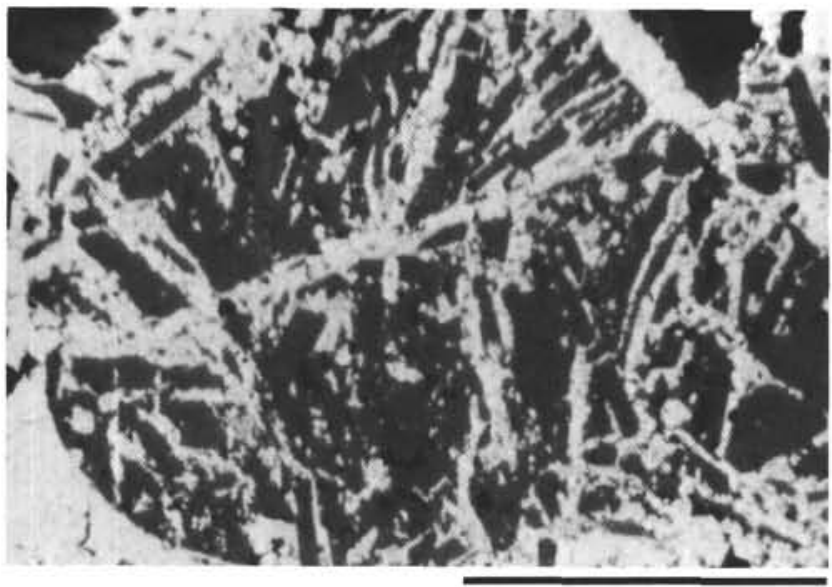

Figure 7. Photomicrograph showing partial replacement of glassy volcanic lithic grain (dark) by pyrite (white) $(40-2,10-12 \mathrm{~cm})$; texture of lithic grain is preserved; bar represents $0.25 \mathrm{~mm}$.

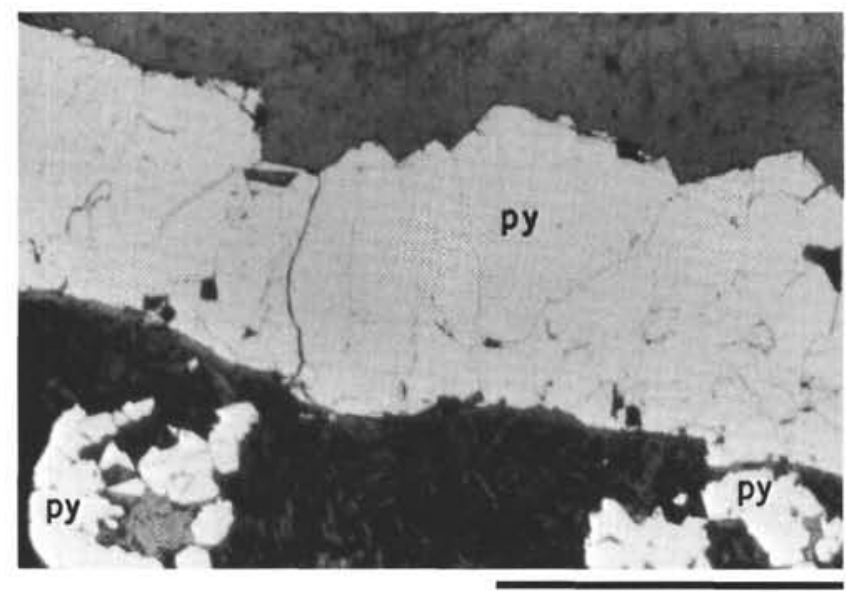

Figure 8. Photomicrograph showing thin rim $(0.2 \mathrm{~mm}$ wide) of pyrite coating surface of trachyte fragment $(41-1,50-54 \mathrm{~cm})$; pyrite also disseminated within trachyte and filling vesicle; $p y=$ pyrite; bar represents $0.25 \mathrm{~mm}$.

The bottom surface of pyrite in contact with trachyte is generally smooth, but locally extends into the trachyte as tongue-shaped masses and thin vesicle linings. Away from the sulfide rim, pyrite occurs as minute, disseminated grains and marginal or weblike replacements of magnetite.

\section{CHEMICAL COMPOSITION}

The bulk chemistry of three samples of limestone from Core 40 that contain sulfide-rich intervals is compared with the average composition for 24 samples of olive limestone and five samples of gray limestone from Unit II (Dean, this volume) in Table 2. Relative to the limestone higher in the section, the sulfide-rich limestone has more $\mathrm{Fe}, \mathrm{Ba}, \mathrm{Mo}-$ and possibly $\mathrm{K}$ and $\mathrm{Sr}-$ and lower V. High $\mathrm{Fe}$ and $\mathrm{Ba}$ contents clearly reflect the dominant iron-sulfide-barite assemblage. The very high Mo content is unusual in that no molybdenite was detected by X-ray methods or microscopy. An alternative site for Mo may be the iron sulfide. Mo is concentrated in pyrites from marine sedimentary rocks (Cambel and Jarkovsky, 1969; Mitchell, 1968).

Higher $\mathrm{K}$ contents in the iron-sulfide-rich intervals correspond to the occurrence of clinoptilolite and jarosite. Although $\mathrm{Sr}$ is relatively abundant in carbonate rocks, the sympathetic relationship between $\mathrm{Ba}$ and $\mathrm{Sr}$ in the three analyzed samples suggests that the high $\mathrm{Sr}$ content in certain zones is due, at least in part, to abundant barite. Marine barite commonly contains 1 to 3 mole $\% \mathrm{SrSO}_{4}$ (Church, 1970).

The abundance of sulfide and sulfate in the ironsulfide-rich intervals has greatly diluted the amount of $\mathrm{Ca}$, and possibly $\mathrm{Mn}$, with respect to mean values in Unit II limestone. The high V content of sulfide-poor relative to sulfide-rich limestone is probably due to more-abundant organic matter in the former. Organic matter is commonly a sink for $\mathrm{V}$ in marine sedimentary sequences (Goldschmidt, 1958), but much of the organic matter within the sulfide layers has been metabolized by anaerobic bacteria.

The iron-sulfide layers contain $\mathrm{Cu}, \mathrm{Zn}$, and $\mathrm{Pb}$ at background levels, which is consistent with the absence of base-metal sulfides.

Electron-microprobe analyses of individual iron sulfide grains from 40-2, 18-20 cm, in limestone, and 41-1, $50-54 \mathrm{~cm}$, in trachyte, show that pyrite and marcasite are very pure phases, with nearly identical compositions (Table 3). Furthermore, there is no apparent compositional difference between iron sulfide from limestone (analyses 1-6) and the underlying basalt (analyses 7-11). In both pyrite and marcasite, the Fe content is slightly in excess of stoichiometric proportions for $\mathrm{FeS}_{2}$. Traceelement contents are low, with the exception of $\mathrm{Cu}$. The consistency of $\mathrm{Cu}$ levels and the absence of any copper sulfide phase indicate that the copper is present in solid solution within the iron sulfide crystal lattice. The low $\mathrm{Co}$ and $\mathrm{Ni}$ contents are within the range of a variety of sedimentary pyrites (Price, 1972).

\section{DEPOSITION OF IRON SULFIDE}

The foregoing data indicate to us that deposits of iron sulfide in Units II and III at Hole 465A are mainly the result of low-temperature diagenetic processes operating in carbonate sediments in the marine environment. This interpretation is consisient with sulfur-isotope data for pyrite and barite from Hole $465 \mathrm{~A}$ presented elsewhere in this volume by O'Neil and Vallier. The sulfide accumulations are notable for their coarse grain size, the abundance and variety of sulfate phases accompanying iron sulfide, the mixture of pyrite and marcasite, the absence of framboidal texture, and the vertically extensive mineralization, ranging from the carbonate sediments of Unit II down into trachyte basement.

Experimental work during the last two decades (Baas Becking and Moore, 1961; Berner, 1964, 1970; Rickard, 1969) demonstrates that pyrite and marcasite (or one of several metastable iron monosulfide precursors) form in low-Eh (anoxic), near-neutral $p \mathrm{H}(6-8)$ environments, provided that (1) organic matter, (2) dissolved sulfate, (3) sulfate-reducing bacteria, and (4) a source of iron oc- 
Table 2. Major and trace elements of sulfide-rich layers and limestone from Unit II, Hole 465A, Hess Rise.

\begin{tabular}{|c|c|c|c|c|c|}
\hline \multirow[b]{2}{*}{ Elements } & \multicolumn{3}{|c|}{ Sulfide-Rich Layers } & \multicolumn{2}{|c|}{ Limestones } \\
\hline & $465 \mathrm{~A}-40-1,145-150 \mathrm{~cm}$ & $465 \mathrm{~A}-40-2,10-12 \mathrm{~cm}$ & $465 \mathrm{~A}-40-2,18-20 \mathrm{~cm}$ & Olive, Laminateda & Gray, Massive $\mathrm{e}^{\mathrm{b}}$ \\
\hline $\mathrm{Si}(\%)$ & $<10.0$ & 12.0 & $<10.0$ & 2.6 & 9.0 \\
\hline & & 2.7 & & 0.83 & 3.2 \\
\hline $\mathrm{Na}$ & 0.71 & 1.6 & 0.60 & 0.15 & 0.75 \\
\hline $\mathrm{K}$ & 0.98 & 1.8 & 0.67 & 0.15 & 0.53 \\
\hline$\hat{\mathrm{P}}$ & $<0.02$ & $<0.02$ & $<0.02$ & - & - \\
\hline $\mathrm{Fe}$ & $>20.0$ & $>20.0$ & 17.98 & 0.34 & 0.34 \\
\hline $\mathrm{Mg}$ & 2.4 & 0.57 & 0.40 & 0.50 & 1.1 \\
\hline $\mathrm{Ca}$ & 5.0 & 2.4 & 0.88 & & \\
\hline $\mathrm{Ti}$ & 0.06 & 0.10 & 0.12 & 0.03 & 0.19 \\
\hline $\mathrm{Ag}(\mathrm{ppm})$ & $<1.0$ & $<1.0$ & 0.6 & - & - \\
\hline & $<0.2$ & $<0.2$ & $<0.2$ & - & - \\
\hline B & 14 & 33 & 41 & - & - \\
\hline $\mathrm{Ba}$ & $>5000$ & 100 & $>5000$ & 56 & 700 \\
\hline $\mathrm{Be}$ & 2.9 & 3.4 & 1.4 & - & - \\
\hline $\mathrm{Cd}$ & $<20$ & $<20$ & $<20^{4}$ & $=$ & $=$ \\
\hline $\mathrm{Ce}$ & $<100$ & $<100$ & $<100$ & - & - \\
\hline Co & $<1.0$ & $<1.0$ & $<1.0$ & 1.0 & 1.8 \\
\hline $\mathrm{Cr}$ & $<10$ & $<10$ & $<10$ & 18 & 5.1 \\
\hline $\mathrm{Cu}$ & 3.6 & 2.3 & 3.5 & 9.2 & 1.9 \\
\hline Ga & $<10$ & $<10$ & $<10$ & - & \\
\hline $\mathrm{La}$ & 29 & 31 & 49 & 25 & 49 \\
\hline $\mathrm{Li}$ & $<100$ & $<100$ & $<100$ & 8.9 & 37 \\
\hline $\mathrm{Mn}$ & 340 & 240 & $<200$ & 700 & 350 \\
\hline Mo & 210 & 220 & 220 & 24 & 14 \\
\hline $\mathrm{Nb}$ & $<50$ & $<125$ & $<50$ & - & - \\
\hline $\mathrm{Ni}$ & 34 & 35 & 33 & 36 & 8.0 \\
\hline $\mathrm{Pb}$ & $<10$ & 14 & $<10$ & - & \\
\hline Sc & $<10$ & $<10$ & $<10$ & 4.5 & 3.3 \\
\hline $\mathrm{Sn}$ & $<20$ & $<20$ & $<20$ & & \\
\hline $\mathrm{Sr}$ & 1100 & 23 & 3600 & 1300 & 500 \\
\hline v & 33 & 18 & 35 & 430 & 280 \\
\hline Y & 22 & 21 & 20 & 17 & 14 \\
\hline $\mathrm{Zn}$ & $<100$ & $<100$ & $<100$ & - & \\
\hline $\mathrm{Zr}$ & 140 & 270 & 150 & 110 & 630 \\
\hline
\end{tabular}

Note: $\mathrm{Fe}, \mathrm{Ag}$, and $\mathrm{Cu}$ for $465 \mathrm{~A}-40-2,18-20 \mathrm{~cm}$ by $\mathrm{AA}$ analysis.

a Average of 24 samples (from Dean, this volume)

b Average of five samples (from Dean, this volume).

Table 3. Composition (wt.\%) of individual iron sulfide grains from Hole 465A, Hess Rise.

\begin{tabular}{|c|c|c|c|c|c|c|c|c|c|c|c|}
\hline \multirow[b]{2}{*}{ Element } & \multicolumn{11}{|c|}{ Analysis } \\
\hline & 1 & 2 & 3 & 4 & 5 & 6 & 7 & 8 & 9 & 10 & 11 \\
\hline $\mathrm{s}$ & 54.03 & 54.44 & 53.72 & 53.82 & 53.67 & 53.68 & 53.05 & 53.05 & 53.55 & 53.66 & 53.45 \\
\hline $\mathrm{Fe}$ & 46.11 & 46.28 & 45.93 & 46.16 & 45.93 & 46.16 & 45.87 & 45.96 & 46.01 & 46.17 & 45.57 \\
\hline Co & 0.07 & 0.05 & 0.06 & 0.05 & 0.06 & 0.06 & 0.05 & 0.06 & 0.05 & 0.05 & 0.04 \\
\hline $\mathrm{Ni}$ & 0.00 & 0.00 & 0.01 & 0.00 & 0.00 & 0.01 & 0.00 & 0.00 & 0.00 & 0.01 & 0.00 \\
\hline $\mathrm{Cu}$ & 0.17 & 0.11 & 0.11 & 0.09 & 0.05 & 0.12 & 0.11 & 0.09 & 0.10 & 0.14 & 0.09 \\
\hline As & 0.01 & 0.00 & 0.01 & 0.00 & 0.01 & 0.02 & 0.04 & 0.03 & 0.01 & 0.00 & 0.03 \\
\hline Totals & 100.39 & 100.88 & 99.84 & 100.12 & 99.72 & 100.05 & 99.12 & 99.19 & 99.72 & 100.03 & 99.18 \\
\hline
\end{tabular}

Notes: $1-3$, pyrite in layer from $40-2,18-20 \mathrm{~cm}$, Unit II; 4 , marcasite in layer from $40-2,18-20 \mathrm{~cm}$, Unit II; 5 , marcasite bleb in large pyrite grain (analysis 1 ), Unit $11 ; 6,7,9,10$, pyrite from sulfide rim on trachyte breccia fragment, $41-1,50-54 \mathrm{~cm}$, Unit III; 8 , marcasite in pyrite (analyses 6 and 7). Unit III; 11 , pyrite lining vesicle in trachyte, $41-1,50-54 \mathrm{~cm}$, Unit III.

cur in sufficient quantity. The sedimentary environment in Unit II at Hole 465A contained all of these features.

Organic-carbon contents up to $8.6 \mathrm{wt} . \%$ were measured in limestone of Unit II (Dean, this volume). The organic matter, largely lipid-rich kerogen of marine origin (Dean and Claypool, this volume), occurs in thin layers within the mineralized interval. Although the amount of metabolizable organic matter may be a limiting factor in the formation of iron sulfide in sediment (Berner, 1970), mathematical models constructed by Rickard (1973) indicate that metal-sulfide deposits (Fe, $\mathrm{Cu}, \mathrm{Pb}$, and $\mathrm{Zn}$ ) containing more than $1 \%$ metal can be produced by bacterial action in sediments with as little as $0.1 \%$ organic carbon.

The presence of abundant, coarse-grained barite forming the matrix of sulfide-rich layers and providing the support for sand-sized lithic grains is direct evidence that dissolved sulfate was abundant and readily able to diffuse through the loosely compacted sediment during early diagenesis. The remains of sulfate-reducing anaerobic bacteria were not seen petrographically, but indirect evidence of these bacteria exists. Simoneit (this volume) has determined that the composition of high lipid contents in claystone from Site 466 on Hess Rise is indicative of bacterial activity in a euxinic environment. Furthermore, strongly negative $\delta^{34} \mathrm{~S}$ values obtained for pyrite from Unit II by O'Neil and Vallier (this volume) are characteristic of bacteriogenic sulfides. Biogenic iron sulfides formed in marine sediments commonly occur in microspheric masses known as framboids, but nonframboidal biogenic pyrite has been produced in the laboratory (Rickard, 1969). In addition, Lambert and Bubela (1970) and Berner (1969) have shown that the migration of metal and sulfide ions, driven by chemical concentra- 
tion gradients in the sedimentary column, can result in layer-like sulfide accumulations, particularly when layers of organic matter are present.

Organic matter in the lower part of Unit II is spatially associated with sandy layers rich in mafic volcanic components, including brown ash and trachyte fragments (Vallier and Jefferson, this volume). Hein and Vanek (this volume) report that ash from the lower part of Unit II is largely altered to smectite. Trachyte basement rock of Unit III is also highly altered (Seifert and others, this volume), but the amount of iron released to ambient sea water is unknown. Release of potassium during alteration of trachyte basement and volcanogenic components in the sediment probably resulted in the formation of clinoptilolite and jarosite.

\section{CONCLUSIONS}

Following cessation of mid-Cretaceous volcanism and subsidence of some volcanic islands on Hess Rise, carbonate sedimentation proceeded on trachyte basement within a shelf or near-shore basinal environment. During subsidence, carbonate deposition continued, concurrent with accumulation of abundant terrigenous volcanic debris shed from nearby subaerial volcanoes. Layers of organic matter were deposited and preserved under what must have been anoxic conditions, possibly resulting from the impingement of the Cretaceous midwater oxygen minimum against the Hess volcanic chain (Dean and Claypool, this volume). Dissolved sea-water sulfate diffusing through the organic-matter-rich layers was reduced to sulfide by anaerobic bacteria. Ferrous iron mobilized during the sea-floor weathering of trachytic ash and glassy trachyte fragments was fixed as pyrite and marcasite (or, one of several iron monosulfide precursors; Berner, 1970; Rickard, 1969) in layers enclosing or in close proximity to the volcanogenic debris and organic layers. Marcasite may have formed in low- $p \mathrm{H}$ microenvironments within the sulfide-rich layers (Rickard, 1969; Stanton, 1972). Barite, co-precipitated with iron sulfide, was corroded and replaced by sulfide as bacterial activity continued. Glassy volcanic lithic fragments were also partly replaced by sulfide. Iron sulfide continued to form until organic matter in and near the detrital volcanogenic layers was entirely metabolized by bacteria, or until the supply of dissolved sulfate in ambient pore fluid was exhausted.

Anoxic sea water carrying dissolved sulfide penetrated downward into the brecciated trachyte, where it encountered dissolved ferrous iron, likely mobilized from the altered trachyte basement rocks, and precipitated iron sulfide on rock fragment and vesicle surfaces.

Although we believe that iron sulfide deposition at Hole $465 \mathrm{~A}$ represents mainly a synsedimentary diagenetic process, some features suggest that elevated temperatures may have augmented or intensified the process just outlined. Abundant barite through the lowest meter of Unit II limestone; high uranium contents (to $200 \mathrm{ppm}$ on a carbonate-free basis) in analyses of all studied rock types (Hein and Vanek, this volume; Hein, unpublished data); extensive brecciation, veining, and alteration of trachyte in the volcanic basement; pyritized sand-size lithic grains; and Ag-bearing clay minerals in at least one sulfide-rich zone (Hein, unpublished data) could have resulted from a low-temperature hydrothermal episode. Oxygen-isotope values for calcite and barite in Cores 40 and 41 at Hole 465A give a concordant formation temperature of $35^{\circ} \mathrm{C}\left(\mathrm{O}^{\prime} \mathrm{Neil}\right.$ and Vallier, this volume), considerably warmer than modern-day deep or near-surface ocean water. Further studies of alteration and sulfide mineralization in the trachyte may provide additional information needed to improve our understanding of the iron sulfide deposits from Hess Rise.

\section{ACKNOWLEDGMENTS}

The authors thank Tracy Vallier and David Piper, U.S. Geological Survey, for careful reviews of this paper. Robert Oscarson directed the SEM studies, and Gerald Czamanske kindly provided sulfide standards for the microprobe analyses.

\section{REFERENCES}

Baas Becking, L. G. M., and Moore, D., 1961. Biogenic sulfides. Econ. Geol., 56:259-272.

Berner, R. A., 1964. Iron sulfides formed from aqueous solution at low temperatures and atmospheric pressure. J. Geol., 72:293-306. 1969. Migration of iron and sulfur within anaerobic sediments during early diagenesis. Am. J. Sci., 267:19-42. $1-23$.

Cambel, B., and Jarkovsky, J., 1969. Rare elements in pyrite deposits of the western Carpathians in connection with genetic problems of mineralization. In Khitarov, H. I. (Ed.), Problems of Geochemistry (Vol. 1): Moscow (Nedra), 266-282.

Church, T. M., 1970. Marine barite [Ph.D. dissert.]. Univ. of California, San Diego.

Curtis, C. D., 1967. Diagenetic iron minerals in some British Carboniferous sediments. Geochim. Cosmochim. Acta, 31:2109-2123.

Edwards, A. B., and Baker, G., 1951. Some occurrences of supergene iron sulfides in relation to their environments of deposition. $J$. Sediment. Petrol., 21:34-46.

Goldschmidt, V. M., 1958. Geochemistry: London (Oxford Univ. Press).

Hein, J. R., and Griggs, G. B., 1972. Distribution and scanning electron microscope (SEM) observations of authigenic pyrite from a Pacific deep-sea core. Deep Sea Res., 19:133-138.

Kelts, K. R., 1976. Marcasite in Miocene calcareous sediments from Hole 315A. In Schlanger, S. O., Jackson, E. D., et al., Init. Repts. DSDP, 33: Washington (U.S. Govt. Printing Office), 867-870.

Lambert, I. B., and Bubela, B., 1970. Banded sulfide ores: the experimental production of monomineralic sulfide bands in sediments. Mineralium Deposita, 5:97-102.

Love, L. G., 1967. Early diagenetic iron sulfide in recent sediments of the Wash (England). Sedimentol., 9:327-352.

Love, L. G., and Amstutz, G. C., 1966. Review of microscopic pyrite. Fortschr. Mineral., 43:273-309.

Mitchell, R. H., 1968. A semiquantitative study of trace elements in pyrite by spark source mass spectroscopy. Norsk Geologisk Tidsskr., 48:65-80.

Price, B. G., 1972. Minor elements in pyrites from the Smithers map area, B.C., and exploration applications of minor element studies [Master's thesis]. Univ. British Columbia.

Rickard, D. T., 1969. The microbiological formation of iron sulfides. Stockholm Contr. Geol., 20:50-66.

1973. Limiting conditions for synsedimentary sulfide ore formation. Econ. Geol., 68:605-617.

Siesser, W. G., 1978. Petrography and geochemistry of pyrite and marcasite in DSDP Leg 40 sediments. In Bolli, H. M., Ryan, W. B. F., et al., Init. Repts. DSDP, Suppl. to Vols. $38,39,40$, and 41: Washington (U.S. Govt. Printing Office), 767-775. 


\section{R. A. KOSKI, J. R. HEIN}

Siesser, W. G., and Rogers, J., 1976. Authigenic pyrite and gypsum in Southwest African continental slope sediments. Sedimentol, , 23: $567-577$.

Stanton, R. L., 1972. Ore Petrology: New York (McGraw-Hill).

Sweeney, R. E., and Kaplan, I. R., 1973. Pyrite framboid formation: laboratory synthesis and marine sediments. Econ. Geol., 68: 618-634.
Vallier, T. L., Windom, K. E., Seifert, K. E., et al., 1980. Volcanic rocks cored on Hess Rise, western Pacific Ocean. Nature, 286: 48-50.

Yakowitz, H., Myklebust, R. L., and Heinrich, K. J.F., 1973. FRAME: an on-line correction procedure for quantitative electron probe analysis. U.S. National Bur. Standards Tech. Note, 796. 